\title{
"Till the muddle in my mind have cleared awa": can we help shape policy using systems modelling?
}

Article

Accepted Version

Lane, D. C. (2016) "Till the muddle in my mind have cleared awa": can we help shape policy using systems modelling?

Systems Research and Behavioral Science, 33 (5). pp. 633650. ISSN 1099-1743 doi: https://doi.org/10.1002/sres.2422 Available at https://centaur.reading.ac.uk/66942/

It is advisable to refer to the publisher's version if you intend to cite from the work. See Guidance on citing.

Published version at: http://onlinelibrary.wiley.com/doi/10.1002/sres.2422/full

To link to this article DOI: http://dx.doi.org/10.1002/sres.2422

Publisher: John Wiley \& Sons, Ltd

All outputs in CentAUR are protected by Intellectual Property Rights law, including copyright law. Copyright and IPR is retained by the creators or other copyright holders. Terms and conditions for use of this material are defined in the End User Agreement.

$\underline{\text { www.reading.ac.uk/centaur }}$

\section{CentAUR}


Central Archive at the University of Reading

Reading's research outputs online 


\title{
"Till the muddle in my mind have cleared awa": Can we help shape policy using systems modelling?
}

\author{
David C Lane
}

Correspondence to: Prof David C Lane, Henley Business School, Whiteknights, Reading, RG6 6UD, England.

E-mail: $\underline{\text { d.c.lane@henley.ac.uk }}$

\section{Repository Note}

This document is the accepted version of the following article:

Lane DC. 2016. 'Till the muddle in my mind have cleared awa': Can we help shape policy using systems modelling? Systems Research and Behavioral Science 33(5): 633-650.

which can be found in its final form at:

http://onlinelibrary.wiley.com/doi/10.1002/sres.2422/full

Note that the published version may have some differences from the version here. In all cases, the published version takes precedence.

If you wish to cite the ideas in this paper then please cite the version published in $S R \& B S$, NOT this version.

Please contact the Corresponding Author if you have any queries.

\begin{abstract}
This paper considers how some well-documented deficiencies of mental models make it difficult to create effective policies, and suggests that systems modelling can begin to address this issue. To illustrate the argument three short cases are presented. These relate to specific domains but demonstrate how systems modelling can illuminate different general phenomena: effects on labour costs (unintended consequences and feedback); fishery management (accumulation and non-linearity) and child protection (worldviews and sensemaking). Six levers for increasing the use of systems modelling in the policy arena are then discussed. The paper closes by emphasising the opportunities for systems modellers in the Anthropocene Era.
\end{abstract}

Keywords: complexity, mental models, unintended consequences, feedback, system dynamics, SSM, worldviews, behavioural operational research, Anthropocene Era 


\title{
"Till the muddle in my mind have cleared awa": Can we help shape policy using systems modelling?
}

\author{
David C Lane
}

Henley Business School

\begin{abstract}
This paper considers how some well-documented deficiencies of mental models make it difficult to create effective policies, and suggests that systems modelling can begin to address this issue. To illustrate the argument three short cases are presented. These relate to specific domains but demonstrate how systems modelling can illuminate different general phenomena: effects on labour costs (unintended consequences and feedback); fishery management (accumulation and non-linearity) and child protection (worldviews and sensemaking). Six levers for increasing the use of systems modelling in the policy arena are then discussed. The paper closes by emphasising the opportunities for systems modellers in the Anthropocene Era.
\end{abstract}

Keywords: complexity, mental models, unintended consequences, feedback, system dynamics, SSM, worldviews, behavioural operational research, non-linearity, Anthropocene Era

\section{INTRODUCTION}

This paper concerns the use of 'systems modelling'; the suite of approaches, tools and techniques that allows issues and situations to be analysed in a rigorous manner using ideas from System Science (Keys, 1988; Jackson, 2003; 2009). It aims to make two contributions. First, to offer a sample of such tools and hence indicate what they can offer to policy discussions in the Anthropocene. Whilst this first element constitutes the majority of the paper, a second contribution offers thoughts on how we might best position ourselves to get those tools put to work in practical situations.

The paper is structured as follows. The next sections explores the context in which we can argue that systems modelling can make a contribution. It does this by briefly considering how some well-documented deficiencies of mental models make it difficult to create effective policies in our complex world and how systems modelling can begin to address this issue. The following section offers three examples of systems models working in this way. Whilst these are of a different scale than the label 'Anthropocene' might suggest, they are presented in their own terms to explore both the potential of systems modelling and the links to general phenomena. The penultimate section identifies six levers for increasing the use of systems modelling in the policy arena, the aim being to make good on the potential of systems modelling by applying the approaches to real problems. The paper closes with a broader consideration of the opportunities for systems modellers in the Anthropocene Era.

\section{"TIS A MUDDLE"}

These are the repeated words of Stephen Blackpool, a character in Charles Dickens' novel Hard Times, as he is confronted with circumstances that he neither expects nor understands. Such bewilderment is not unusual and both its roots and our response to it bear examination. We begin with three specific cases.

\section{The Complexity We Confront}


To reduce costs a company cuts pay rates - only to see workers leave, productivity fall and costs rise further. A fishing fleet grows to a size which destroys the stock of fish, removing what could have been a sustainable source of both protein and profit. A teacher reports bruises on a child apparently caused by his mother - but seeing this as the only interpretation will fail to address the real problem in the family.

These cases are instances of a broader problem. Today, in the Anthropocene Era - an era in which human activity is of a scale to have effects on our global environment (Crutzen \& Stoermer, 2000; Crutzen, 2002) - we live out our lives within large, complex social/physical systems. In those systems cause and effect are often separated in space and time. Consequences are hard to anticipate. Causality is difficult to understand. It is hard to make sense of what happens around us. Describing similar effects, Morton ((2010)) uses the concept of 'hyperobject'; phenomena of such scale, complexity and longevity that they seem unrelated to specific times or locations and defy human understanding, perhaps even human perception.

There are two unwelcome corollaries of this, exemplified in the three cases. The first is that well-intentioned policies may fail. But hand-in-hand with this is a more existential corollary, which is that those social / physical systems, "... are no longer accessible to immediate lived experience and are often not even conceptualisable for most people" (Jameson, 1990, p. 349). Whilst this comment concerns the apparatus of capitalism, it applies more generally. In many situations, daily lived experience becomes capricious, incomprehensible, senseless, even alienating. Happily, this is not always true - as we explore below.

\section{Our Mental Models}

These unwelcome corollaries have much to do with how we think when we try to deal with complexity. One way of understanding that thinking is to view it in terms of our mental models, the abstract sets of ideas in our heads that we use to understand the world (e.g. Doyle \& Ford, 1998; 2000). What is known about these mental models does not make for encouraging reading, especially as it applies to all of us. Based on the work of Dörner (1990; 1996) and Axelrod (1976), findings from Decision Theory (Howard, 1966; Tversky \& Kahneman, 1974; 1981; French, 1988; Hammond, et al., 1998) and the various studies described by Plous (1993), and the emerging area of Behavioural OR (Franco \& Hämäläinen, 2016; Kunc, et al., 2016) we know the following. People - we - have limited cognitive capacity. We tend to think that for each effect there is a single cause. We assume that causal chains are short. We do not think in terms of feedback effects. We find it hard to accept, even see, information we do not expect. When we try to explain things, we are satisfied the moment we feel we have found a convincing cause for something and we stop searching for more complex explanations. We try to confirm our own explanations rather than challenge them.

Another way of looking at these effects is offered by Sims (2005). He describes two reactions to unacceptable human behaviour in an organisation. A pluralistic or relativistic view endeavours to make sense of the complex motivation behind seemingly incomprehensible actions. However, at some point such attempts at interpreting behaviour as merely 'distinctive', or 'misguided', or 'having an alternative point of view' can break down. The alternative is to label an individual as "simply a bastard": this provides the "relief of not having to go through any more layers of explanation" and "relief from complexity" (ibid., pp. 1625, 1630 \& 1626 respectively). In other words, we use poor search strategies combined with naïve mental models.

\section{The System Science Response}

It is because Stephen Blackpool cannot understand the hardship of his immediate lived experience (c.f. Jameson above) that he responds repeatedly by describing his life as 'a muddle'. As signalled earlier, such 
reactions can sometimes be avoided when we have a mental model of sufficient richness. If we have such models, and if our interaction with the world is mediated by them, then we have a chance to understand and to shape our world. This suggests one response to the 'muddle': to help craft policy we could try creating useful models.

The field of System Dynamics cites a deep understanding of mental models as the most significant means by which systems can be managed (Meadows, 2008). In Cybernetics the argument is made that the 'variety' of the world can only addressed using models of a similar level of complexity (Ashby, 1958; Conant \& Ashby, 1970). The same response is seen across the wide range of approaches, tools and techniques that System Science offers (Keys, 1988; Jackson, 2003; 2009). The argument is exemplified in the cases which form the following section. For now, we may usefully quote the oceanographer James Rennell:

"The formation of a great number of facts into a system, may, it is presumed, prove of use in impressing those facts on the mind more strongly than if they were left to operate independently of each other. For oftentimes a fact makes less impression, when standing naked and alone, than when it makes part of a system, which operates like a band to keep the parts together in their proper places, when they may happen to explain and illustrate each other.... " - James

Rennell, 1832, p. 5

Rennell's 'system' which 'operates like a band' gives coherence to empirical data but his argument and imagery may no less persuasively be applied to models which allow facts and theories to be represented, interrogated and communicated. Here, perhaps, is a way through the muddle of complexity. Three examples of systems models working in this way form the next section.

\section{SYSTEMS MODELS AND POLICY}

\section{To Understand Unintended Consequences and Feedback}

The managers of a company wish to reduce their total costs. Amongst the cost-cutting policies that they implement is a reduction in the 'labour rate', the pay per hour for staff. This approach can be represented using a systems modelling tool, a causal loop diagram or CLD (Forrester, 1968a). A balancing loop represents the rationale of moving total costs down to their desired level, via a reduction in labour rates (see Figs. 1, LHS). The approach is plausible. The policy may well work - Pfeffer describes its applicability to certain industries (Pfeffer, 1998; 2007). However, he also describes how cutting costs may have unexpected consequences.

There is a range of possible unintended consequences of this policy and some of these can also be mapped (Lane \& Husemann, 2008). These ideas are represented in Figs. 1, RHS.

Cutting wages motivates staff to look for other work. In an industry with appreciable staff mobility, this increases staff turnover. With an increased 'churn rate' of staff the average time in post will reduce and so, in time, the average experience of staff reduces. In industries where little skill is needed for the work, and/or in which training to the desired level is rapid, this may have no consequences. However, in some industries this results in a reduction of productivity, a reduction in the rate at which work gets done. This is an unintended consequence of the policy - and it can undermine it utterly. If this effect does operate then more time is needed to complete a given set of tasks, or accomplish a given work rate. This can have the effect of increasing the actual cost of labour: cost per unit time may have decreased but if more time is spent per task then the cost per task may increase. Not only is this an unintended effect, if the company persists in the original policy 
it serves to create a reinforcing loop which, far from reducing costs, may dominate the system and drive costs upwards (see loop 'R1' in Figs. 1, RHS).

Similar arguments apply to other possible consequences. Work may be done less well and the reduced quality must be re-worked, costing more time. There may be other costs, possibly only arising with even longer delays. For example, a poorly made item may be returned by its purchaser with loss of customer good-will that can be evaluated in financial terms; or a badly made electrical item may cause damage and direct financial loss, not to mention harm to its user. Again, in both cases, the pursuit of the original policy in the face of such consequences would produce two more reinforcing effects (see loop 'R2' and 'R3' in Figs. 1, RHS). If these loops dominate then there is an increase in costs.

Total Costs
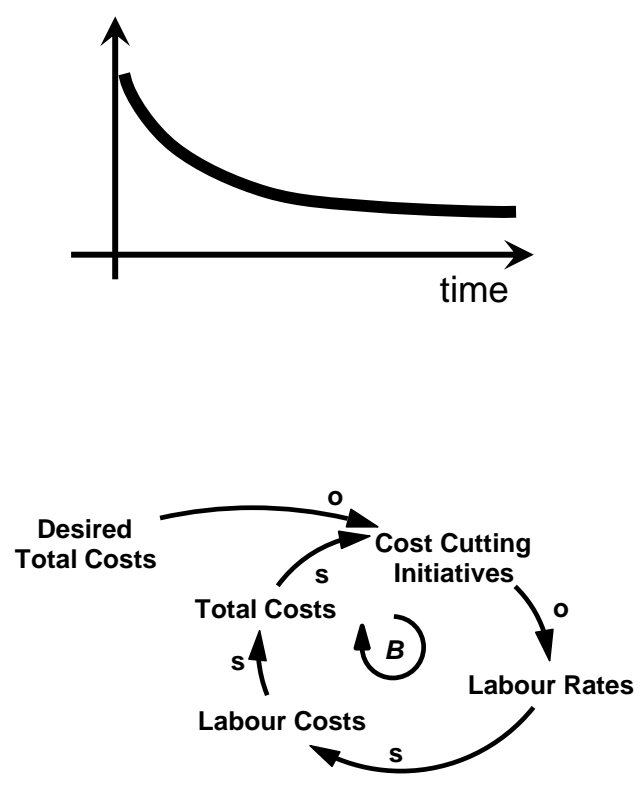

Total Costs
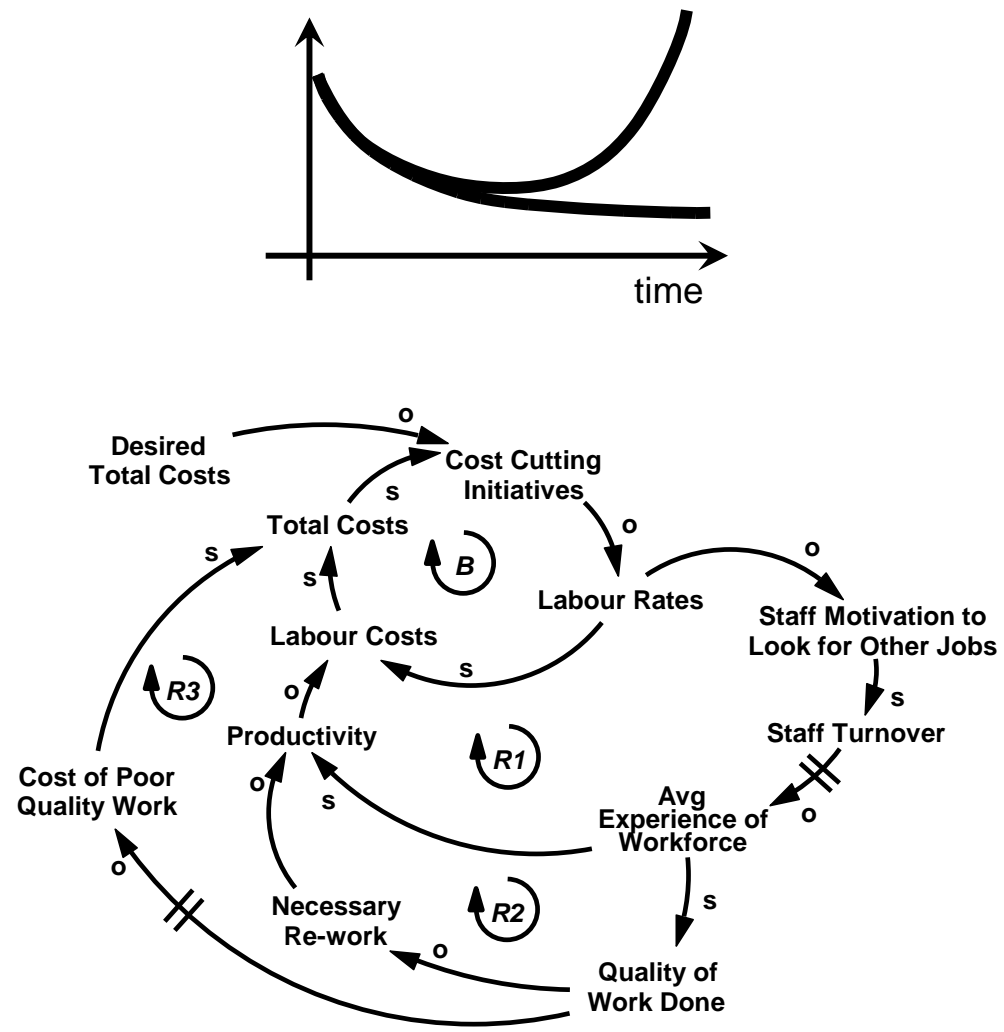

Figures 1: Effects of cutting pay: possible behaviour over time (top) and CLDs illustrating the causal mechanisms (bottom). LHS: a system with simple consequences, the balancing loop dominating behaviour. RHS: a sample of more complex, unintended consequences, one or more of the reinforcing loops eventually coming to dominate behaviour. Arrows marked 'o' represent causal influences which, ceteris paribus, cause changes in the opposite direction; ' $s$ ' labels indicate changes in the same direction. The double lines indicate a delayed effect.

These effects may not occur; they are context dependent. The complex array of possible mechanisms and consequences shown in Fig. 1, RHS may not be in place. However, it is a bold manager who asserts that his world is entirely captured by Fig. 1, LHS. The alternative is to interrogate the policy using mapping to explore the possibility of 'other' policy consequences. Or collect data on previous similar situations. Or simply try the 
policy but be open to learning about other consequences: monitor staff turnover, re-work rates, customer complaints. Implement the policy whilst being open to the possibility of these and other effects occurring, evaluate them in feedback terms and be willing to alter the policy if its effects are not as desired.

Surprising and unexpected consequences may variously be thought of as 'unintended consequences', or 'unanticipated consequences'. What they are not is 'side effects', because they are no less effects than the intended ones. ${ }^{1}$

The need to consider unintended consequences is well-established as an issue in social analysis (Merton, 1936) and oft repeated as good advice in policy analysis (e.g. Rosenhead, 1992; Barber, 2015). However, this is easier said than done since, "Surprise is an unavoidable fact of life, and the assumption that decision makers can anticipate every eventuality that might befall them is highly demanding" (Feduzi \& Runde, 2014, p. 272). Hence the comic but insightful observation that the advice "Expect the unexpected ... is a) glib, and b) a contradiction in terms" (Adams \& Perkins, 1985, p. 195). However, pace Adams, don't panic; it is possible to make a start, as described in the case here. As a further example, an understanding of the unintended consequences of past policies and a rigorous attempt to consider the consequences of proposed new policies was central to a review of the child protection system in England (Lane, et al., 2016a; 2016b).

Moreover, the concept of unintended consequences is relevant beyond pay rates and child protection, being useful when considering the Anthropocene. A key text of the environmentalist movement, Silent Spring, described the damaging 'side effects' of DDT usage (Carson, 1962) and prompted other researchers to discover further unintended consequences, such as "calves ... made ill by heptachlor from their mothers' own milk" (de Steiguer, 1997, p. 33). And who but a few specialists would have anticipated that the creation in 1830 of the coal-powered Liverpool \& Manchester Railway would be one element of a chain of events leading, nearly two centuries later, to a change in direction of the drift of the Earth's pole (Bradley, 2015; Adhikari \& Ivins, 2016)? Understanding unintended consequences and feedback is a necessary part of policy making in the Anthropocene and systems modelling can assist.

\section{To Understand Accumulation and Non-linearity}

An area of ocean is fished. This provides profit for the fishing companies involved, work for the local community and a source of protein for the region. New fishing boats can be built - necessary since wear and tear create a need for a replacement. The fish are a renewable resource, their numbers growing rapidly until limited by the capacity of the ocean to support the population. The more fish there are, the easier they are to harvest.

The story could continue almost indefinitely but it does not. Profit and the expectation of future profit based on the recent past drive investment in more boats. The fish stock falls and is eventually driven towards destruction. Fishing wanes, or becomes uneconomical and, along with the fish population, the industry dies. This repeated story is seen in the world (Moxnes, 1998) and can be re-created via a computer-supported 'game' called Fish Banks Ltd (Meadows, et al., 1989). Amongst the possible explanations (see Barnabè, 2015) the most widely used is the 'tragedy of the commons' effect (Hardin, 1968). When agents involved in fishing have unrestricted access to the stock of fish, and no one has an over-arching responsibility for the 'common' resource, it makes sense - particularly in competitive terms - for each agent to increase their 'take' of that resource and so over-invest in boats. The result is destruction.

\footnotetext{
${ }^{1}$ For similar but more caustic view relating to the pharmaceutical industry, see Prebble (2012, p. 78):

"Dr James: This can't be pulled apart. We're kidding ourselves to think it can.

Toby: $\quad$ This is why we do trials! We're here to record side effects and if aggression is a side effect we'll note it.

Dr James: They're not side effects, Toby, they're just effects you can't sell."
} 
This is a powerful explanation which doubtless applies to many of the situations in which this behaviour is seen. However, it is not the whole explanation. This can be demonstrated by making a single change to the scenario: reducing the number of fishing companies to one. Exclusive property rights should mean that the company sees the resource as its responsibility so that the motive not to over-invest and over-fish is clear and policies can be used which are sustainable. The experiment is conducted using a computer simulation but the result for what is now a one person game are striking: destruction of the fish stock still occurs (Moxnes, 1998; 2000). The ideas of accumulation and non-linearity can be useful when trying to understand this situation.

The harvesting of a renewable resource in a sustainable way has been the subject of considerable mathematical modelling (see Vincent \& Skowronski, 1981; Murray, 1989, for surveys). Here we convey the nature of the interactions in this situation using the iconography of System Dynamics (Forrester, 1961a; 1961b). This visually represents a key distinction: the difference between stocks (like bathtubs, with 'stuff' flowing in or draining out) and flow rates (the amount of 'stuff' flowing in or out in a certain time.

The fleet size is a stock (see Fig. 2). It increases via an inflow of new building generated by profit. It is drained as boats are scrapped. The number of fish is also a stock. It is reduced because a harvesting rate depletes the population. This is an outflow, its rate depending on the catch per boat and the number of fishing boats. The fish stock also changes without any human activity. Fish are born at a certain rate which depends on the current number of fish. That would be an inflow, an accumulative process. However, as the fish also die naturally the net effect on growth - birth minus deaths - can sometimes be negative.

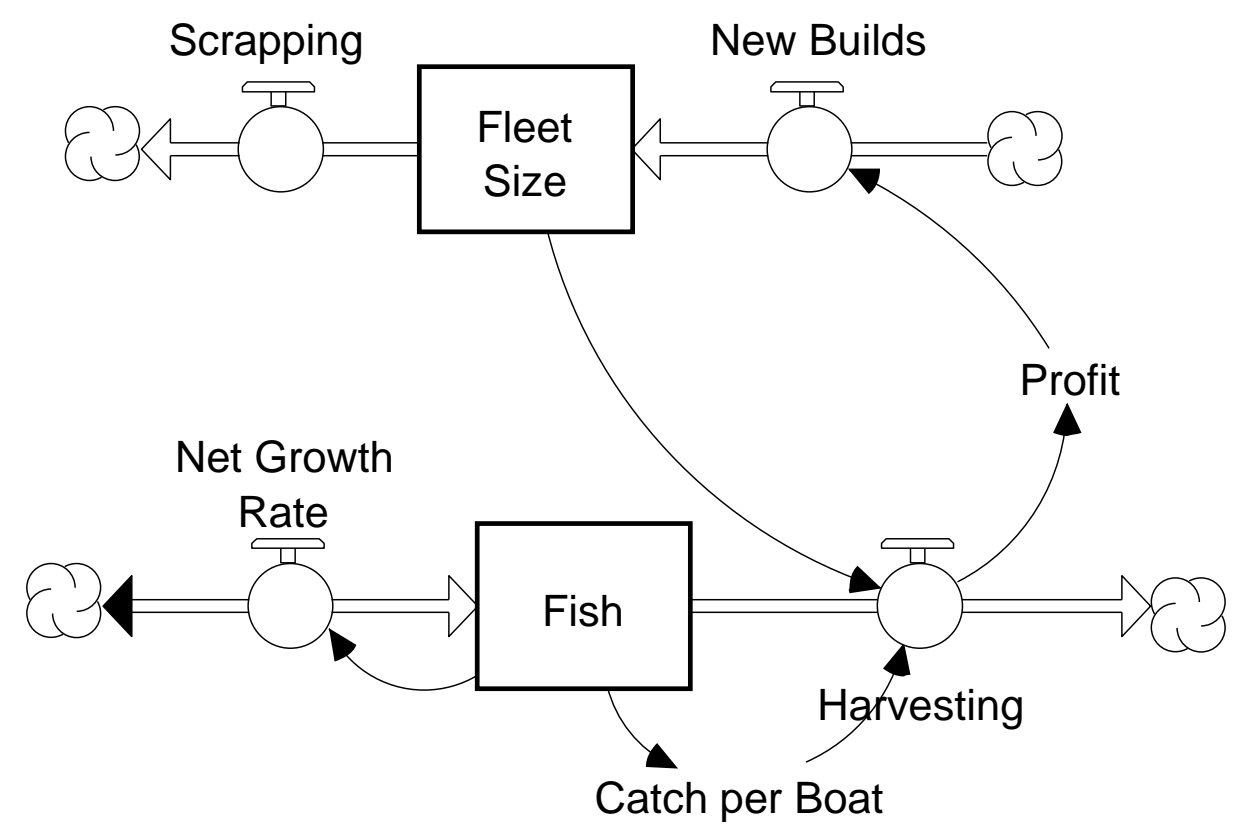

Figures 2: Stock/flow diagram of a fishery management situation. Based on Moxnes (2000).

The implied relationship between the variables is important. For example, the effect of fish numbers on the catch per boat is an instantaneous, functional effect. When stocks and their flows are involved this is not true. Looking just at the fish stock, either a differential or an integral perspective could be used:-

$$
\frac{d \text { Fish }}{d t}=\text { Net Growth Rate }- \text { Harvesting }
$$

or 


$$
\text { Fish }(t)=\int(\text { Net Growth Rate }- \text { Harvesting }) d t+\text { Fish }(0)
$$

A stock therefore represents a 'history' of the decisions that have influenced its inflows and outflows. This has important effects on the behaviour over time of the system.

The second idea that is useful here is non-linear relationships between two variables. Two of these are shown below (Fig. 3).

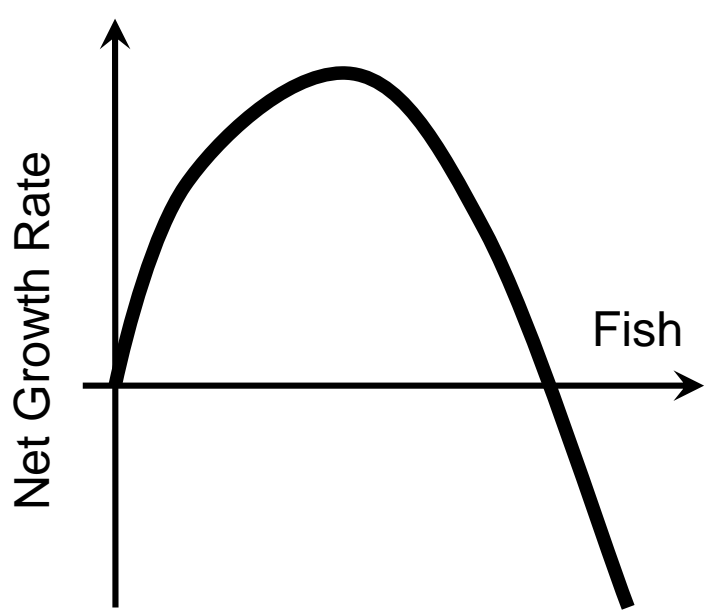

Net Growth Rate $=f_{1}$ (Fish)

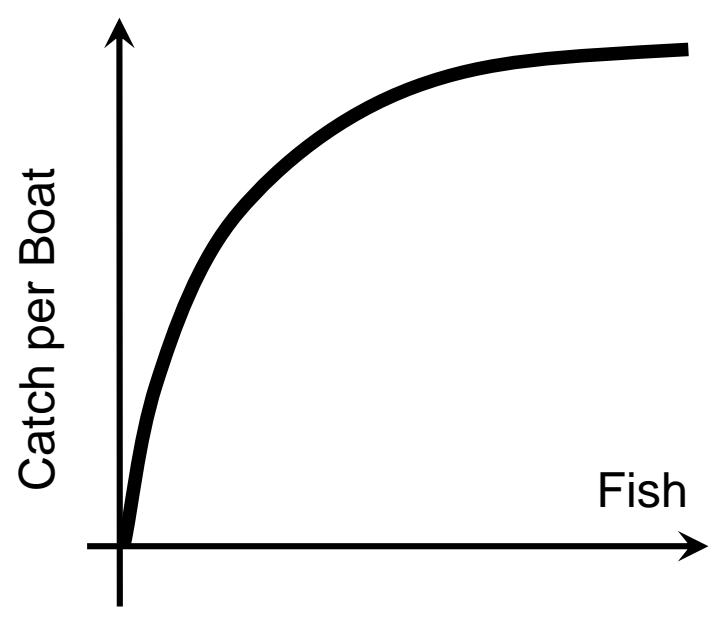

Catch per Boat $=f_{2}($ Fish $)$

Figures 3: Qualitative sketches of two of the key non-linear relationships in the fishery management situation. LHS: the effect of fish stock on net growth rate. RHS the effect of fish stock on the catch per boat.

The net growth rate graph shows that births minus deaths is a function of the existing fish stock. For low numbers of fish, food is plentiful and reinforcing growth occurs, with births greater than deaths. As the population rises food becomes more scarce, births decrease, deaths increase and the net birth rate peaks and falls away. Eventually, in very crowded circumstances, deaths outnumber births and the natural net growth becomes negative.

The number of fish that each boat in the fleet can catch also depends on the number of fish. This is because for small populations fish become harder to find.

It is by bringing together the ideas of accumulation and non-linearity that the nature of the fishery management problem can best be seen. Figure 4 unites the changes to the fish stock in one qualitative graph, showing how harvesting pulls down the growth curve. The top line shows the situation for a constant, 'moderate' fleet size. The fish stock is stable at zero, has an unstable steady state at a middle value, and a stable steady state at a high number of fish. This looks like a healthy and robust ecosystem to have. The bottom line in the figure involves a larger fleet. Now the only steady state is zero because the fleet size is so high that the dynamics of fish births and death are not, in themselves, enough to sustain any other equilibrium population. The result is that the fish are destroyed. This is the common outcome of the experiment; "The 
median participant built a fleet 92 percent above the fleet size that maximized the net present value given full information," (Moxnes, 2000, p. 328).

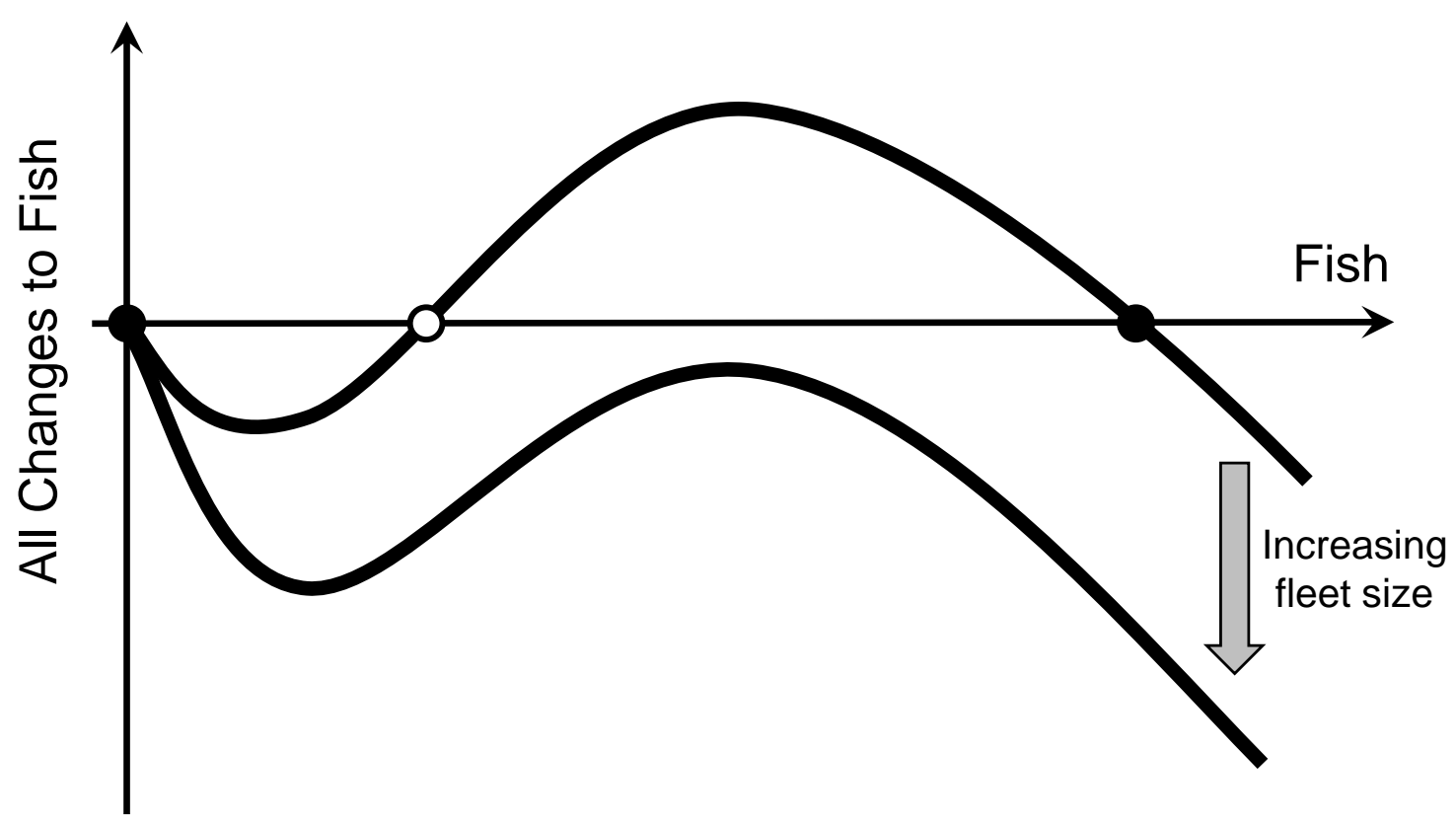

Figure 4: Qualitative sketch of the overall relationship between the number of fish and how fish numbers change, shown for two different (constant) fleet sizes.

Looking at the LHS graph of Fig. 3 the solution might seem clear: never harvest at a rate greater than the maximum net growth rate indicated by the peak there. This is a useful insight but the situation is more complex still. The number of boats influences the harvesting rate; the first number can change and therefore so can the second, whilst the total effect on the fish stock needs to be looked at in the non-equilibrium terms outlined in Fig. 4. However, when confronted with an ocean of fish (even virtual ones within a simulation model) little or none of the information described above is known (at least numerically) or fully understood. It becomes hard to search for the best harvest, hampered by misperceptions in the feedback from experiments. The operation of stock/flow relationships can be hard to work through in one's head (Booth-Sweeney \& Sterman, 2000) whilst humans are poor to anticipating the effects of non-linearities (e.g. Wagenaar \& Sagario, 1975; Wagenaar \& Timmers, 1979).

As a result, even though some players are aware that there may be a problem with the fish stock, "The typical behavior in all the experiments was to delay necessary protective measures, because the situation did not look sufficiently severe at the moment" (Moxnes, 2000, p. 330). This has little to do with a commons problem but derives from the fact that humans find it difficult to intuit the behaviour of systems involving stocks and non-linearities (Forrester, 1961a; 1970a).

Yet such systems are everywhere. The idea of accumulation is found in records of bookkeeping from the ancient Near East (Nissen, et al., 1993) and seen in the concept of the 'carbon bathtub' (Kunzig, 2009), whilst non-linearities are not only all around us in the world itself (Kovbach, 1960) but appear to be an advantageous property of our own minds' perception of it (Fechner, 1860; Sun, et al., 2012). The consequences can be significant: returning to Silent Spring, although Carson describes a host of unintended consequences of DDT 
usage she also uses the concept that chemicals linger for extensive periods as a result of accumulation processes, whilst public difficulty in understanding climate change has been linked to a failure to understand the distinction between stocks and flows (Sterman \& Booth Sweeney, 2007). Regarding non-linearities, in an earlier age, the human brain's non-linear perception of light played a role in resistance to the heliocentric theory (Kremkow, et al., 2014). ${ }^{2}$ Yet an understanding of these ideas, and the simulation of such effects can contribute significantly to policy making (Kim, et al., 2013).

The relevance to the Anthropocene becomes even more clear if one considers the model developed by Jay Forrester for the Club of Rome described in World Dynamics, and from which The Limits To Growth emerged (Forrester, 1971; Meadows, et al., 1972). Fig. 5 reproduces the first draft of the diagram of that model: as well as complex chains of consequence it has stocks and flows as well as non-linear relationships. This, and the resulting stream of work, have significantly influenced public thinking regarding environmentalism and resource limitations and Forrester's original model has been seen as the founding work of global modelling (de Steiguer, 1997; Rome, 2015). Its influence continues (e.g. von Weizsaecker, et al., 1995; Wackernagel, et al., 2002; Lenton, et al., 2008; Rockström, et al., 2009; Tollefson, 2009; MacKenzie, 2012).

Understanding accumulation and non-linearities is a necessary part of policy making in the Anthropocene and systems modelling can assist.

Figure 5: See following page.

2 It was a widely accepted - though now known to be erroneous - 'fact' in the Sixteenth Century that Venus was at a constant distance from Earth. This provided a potential refutation of the theories of Galileo and Kepler (Chalmers, 1982). 


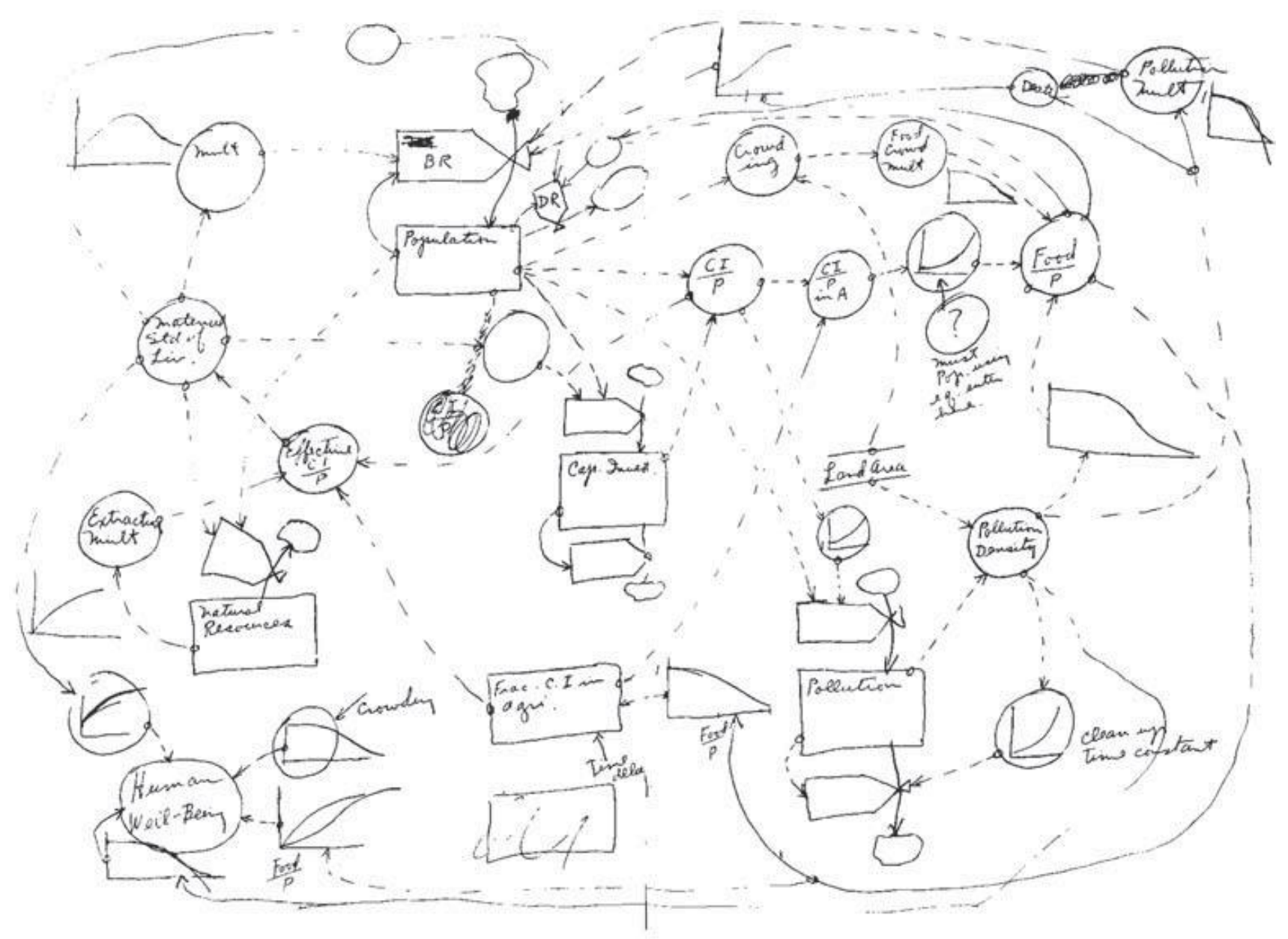

Figure 5: First draft stock/flow diagram for the World Dynamics model. From Forrester (1970b). Note the presence of stocks, inflows, outflows and non-linear relationships.

\section{To Understand Worldviews and Sense-making}

A teacher reports a number of instances in which she has seen bruises on the arms of Daniel, an 11 year old boy in her class, and also noticed his acting in a withdrawn and disconsolate manner. ${ }^{3}$ There is no link with sport, whilst playground bullying seems not to be the cause because the bruises are seen first thing on Monday mornings. Daniel lives with his mother, Lindsey. Along with a Head of Year, the teacher gains the boy's trust sufficient for him to admit that his mother sometimes loses her temper and grabs his arms roughly. The situation is referred to Children's Services and a child and family social worker looks into the case by talking with Daniel.

Lindsey and Daniel's family can be thought of as a 'human activity system', a collection of appreciative, or purposeful activities that are meaningful for those involved (Checkland, 1981; Checkland \& Casar, 1986). A way of exploring such systems is to use the characteristics from the CATWOE framework of Soft Systems Methodology, or SSM (Smyth \& Checkland, 1976; Checkland, 1981). These are listed in Table 1.

3 This example is not drawn from any specific case and it does not purport to represent the opinion of any teacher, or social worker. It has been developed to illustrate the nature of the problems that arise in child protection and the theories and interpretations that might be applied to the complex circumstances that arise. 
Customer

Actors

Transformation

Weltanshauung

Owner

Environmental factors
- Who suffers and who benefits from the system?

- Who makes the Transformation happen?

- What input is changed into what output?

- What understanding of the world makes the system meaningful?

- Who can change or close down the system?

- What aspects outside the system shape its operation, need to be born in mind, and are taken as 'givens'?

Table 1: Main features of a Human Activity System as suggested by the CATWOE mnemonic, derived from Checkland's Soft Systems Methodology.

One use of CATWOE might result in the analysis shown in Table 2. In this analysis the acts of violence are the key 'data point' and are seen as the result of unexplained anger or even malice. Daniel suffers the effect of the system, with Lindsey possibly even benefiting in some way. Lindsey is the central actor in the situation (no other parents or carers are on the scene). Anger management training for Lindsey is a possible intervention but it may be necessary for the courts to remove Daniel from his home for a period to prevent a wholly unhealthy situation from continuing.

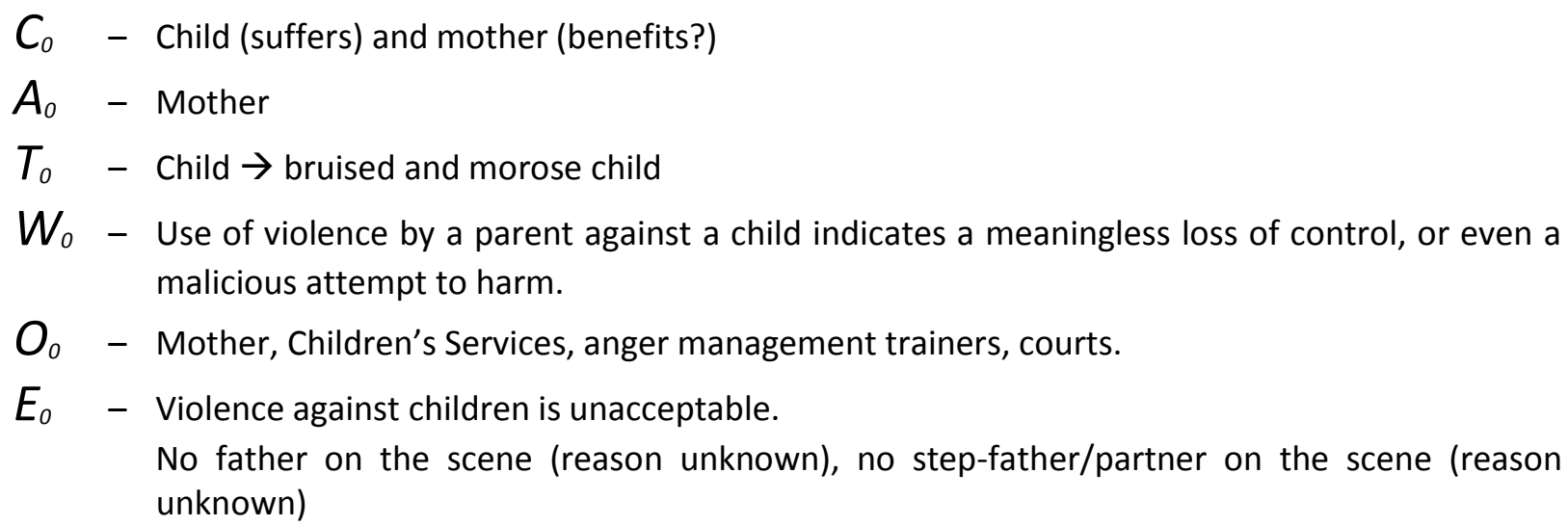

Table 2: A straightforward CATWOE analysis of the Daniel \& Lindsey case.

An alternative analysis retains the importance attached to the violent behaviour but changes the interpretation of this key 'data point'. What might be generated is the sort of rich understanding of a family situation that results from a skilled and experienced social worker's spending time with the parties, gaining their trust and eliciting their accounts of actions and motivations. Alternatively, it might result from examining each attribute of the above CATWOE and exploring the possibility that there may be another explanation, or 
that other factors may be in play. We might imagine conversations with Daniel and Lindsey which, structured around the CATWOE, provide this richer data and perhaps the following story emerges.

Daniel's mother and father, Paul, are separated. It was the mother who brought this situation about five years ago. Lindsey thinks that Paul is both a poor rôle model and that he is uninterested in his son. She has discouraged contact between the two. However, Daniel has reached an age when he is interested in meeting his father and increasingly insistent on trying to spend time with him. Paul has reluctantly agreed to Daniel's staying with him some weekends. As a result there have recently been instances of Daniel's being poorly treated on visits to Paul (Daniel describes finding no bed made up for him, being asked to entertain himself alone, or even being brought home first thing one Sunday morning when Paul's new partner visited). Daniel does not understand Paul's behaviour and argues with Lindsey for more weekends with his father. Lindsey is very concerned that Daniel will get hurt emotionally if he comes to realise his father's lack of interest in him but she has difficulty articulating this to her son. In trying to protect Daniel she admits that she has had furious exchanges with him as she tries to persuade him to stop visiting Paul. At times she has roughly grabbed his arms during these arguments. She regrets this very much but sees it as the only way to be the good mother she desperately wishes to be.

Using CATWOE could therefore yield the analysis shown in Table 3. Its subtly different worldview leads to something akin to an 'issue-based' account, in that it is "... chosen for its relevance to what the investigator and/or the people in the problem situation perceive as matters of contention" (Checkland, 1981 p. 317).

$C_{1}$ - Child (intended beneficiary) and mother (suffers but benefits)

$A_{1}$ - Mother

$T_{1} \quad$ - Child hurt by jilted and disheartening attempts to engage with uncaring father $\rightarrow$ child protected from emotional hurt of such failed attempts.

$W_{1}$ - Use of violence by a parent against a child indicates a clumsy attempt to save the child from other harm.

$O_{1}$ - Mother, Children's Services, parenting skills trainers.

$\mathrm{E}_{1}$ - Violence against children is unacceptable.

Father not on the scene (he is perceived to be uninterested in his son) but sought out by son, no step-father/partner on the scene (reasons unknown)

Table 3: A CATWOE analysis of the Daniel \& Lindsey case which delves further into the complexities of the situation.

Whilst both uses of SSM suggest interventions to halt the violence that Daniel experiences, they provide different suggestions for quite which intervention is appropriate. The first CATWOE might suggest a more punitive stance, aimed at teaching Lindsey self-control techniques or, ultimately, at removing Daniel in a 'child rescue' approach. Both actions ignore Lindsey's motivation and implicitly attack her aspirations as a parent. They may not be effective for Daniel in the long run. The second CATWOE is, naturally, just as insistent about the need for the violence to end but includes the issue of Paul's attitude (or at least Lindsey's perception of it) and acknowledges the aims behind the violent acts. Lindsey's behaviour is explicable in a very different way than that of the first analysis. It therefore becomes possible to engage with her in a way consistent with the 
insight that, even whilst being unacceptably aggressive, she may have the best interests of her son at heart. Now, rather than 'child rescue', a 'family preservation' approach seems appropriate (Mansell, et al., 2011). Hence, an intervention involving the development of Lindsey's parenting skills might be used, an intervention which tentatively acknowledges and works with the grain of her declared aspiration to be a good parent to Daniel.

It is worth restating that these insights could be produced by a capable social worker, without any Soft Systems Methodology. However, SSM is a way of deliberately bringing to bear system science ideas and can help in finding interventions that are both 'systemically desirable' and 'cultural feasible' (Checkland \& Scholes, 1990). It is also known that other systems approaches can contribute usefully in situations of distinct, even conflictual, perspectives (Bryant, 1984; Vennix, 1996; Lane, 1997; Klein, 2000; Black \& Andersen, 2012).

The importance of making sense of situations is emphasised beyond the system science community (Weick, 1995). The perils of not exploring different 'worldviews' are also widely described (though the terminology varies). For example, Nutt cites the work of Linstone and argues that viewing problems from more than one perspective can help avoid the trap of conducting only a 'limited search' when looking for a good decision (Nutt, 2002, after Linstone, 1984). Similarly, King and Crewe (2014) see a number of significant public policy failures in the UK as largely attributable to politicians' separation from the lived experience of most of the population; a 'cultural disconnect'.

Whilst the example here is from child protection there is a link to our understanding of the Anthropocene. Hoffman and Jennings (2012) report that cultural worldview is an indicator of uncertainty about global warming and goes on to argue for engagement with 'cultural and psychological dimensions' to understand the questioning of natural scientific findings. Similarly, Lewandowsky et al. (2013) recommend that an understanding of the motivated reasoning behind actions is needed to improve communication between these camps.

Understanding different worldviews and sense-making activities is a necessary part of policy making in the Anthropocene and systems modelling can assist.

\section{Levers for Bringing Systems Modelling Deeper into the Policy}

\section{Arena}

The cases in the previous section aim to explore and illustrate the power of systems modelling. Of course, to have opportunities to apply systems ideas some element of luck is needed to be in the right place at the right time. However, remember what Louis Pasteur said: "chance favours only the prepared mind" (Vallery-Radot, 1911, p.88). In this section we would like to think about what we can do to prepare; to ask what levers exist for us all to improve our 'cyber-systemic possibilities' for shaping policy using systems modelling?

Here are some thoughts to get us thinking and talking about this. They over-lap and are connected - naturally; we are dealing with complex systems. They can therefore be illustrated using a systems map (see Fig. 6). 


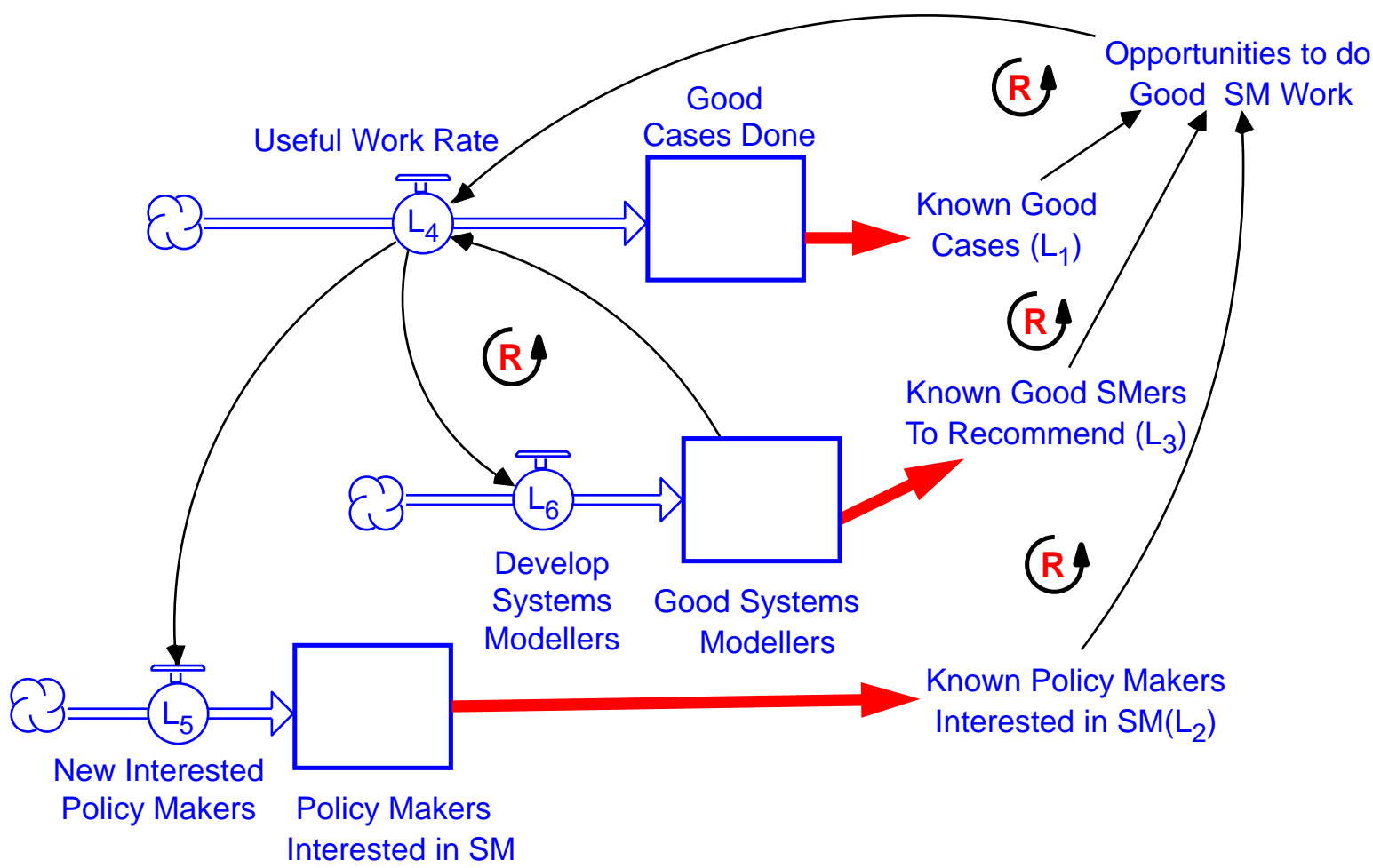

Figure 6: Stock/flow diagram representing the inter-connected levers for improving the use of systems modelling in the policy arena.

The levers can be understood as two sets of three. The first set creates instantaneous effects (note how they all use an active verb).

L1. Know good cases to cite. It is important to be able to give an example of previous situations in which systems modelling has been of practical use to a policy maker. It is an obvious question for a potential client to pose: Where has this systems stuff worked before? A ready answer, brief but with telling detail, can be critical in making an opportunity to do more systems work in the policy realm

L2. Know about policy makers interested in systems modelling. It is worth identifying and remembering who to keep in contact with, who to spend time approaching, if we want to do policy modelling. Not all policy makers are interested, or will champion systems-based work so knowing the ones that are, and knowing what issues they are currently wrestling with, is an efficient way of finding more opportunities.

L3. Know good systems modellers to recommend. Many readers will want to do the work themselves - and that may be the answer. But confronted with the question 'Where can I get people to do system modelling?' you might find that you are busy, or that skill in another system approach is what is really needed. Knowing people you can recommend can allow a policy maker to get the help they need.

These three are useful levers for creating an immediate opportunity to use systems modelling in the policy arena. In contrast, the second set of three levers creates accumulated effects, effects which have the potential to endure . 
L4. Make sure that useful work is done. Grasp every opportunity and do good work. This flow of work then adds to the stock of good cases of systems modelling having been used. It is this that allows point (1) above to take place.

L5. Work on getting more policy makers interested in systems modelling. This is best done by doing good work and helping policy makers to get the best from it. That experience adds to the stock of those who have been helped and who become those champions mentioned in point (2) above.

L6. Develop systems modellers. The experience of doing useful work is a critical element. You may become more experienced yourself or it may be others who improve. Either way, this adds to the stock of good systems modellers that are around and this is what point L3 above needs.

Creating the three stocks is important but they are invisible unless we do something about it. That is why it is equally important to make sure that the bold links are created, to make sure that the stocks are visible. Now we can see that the two sets of three are not separate at all but mutually supportive, indeed, reinforcing (see Maruyma, 1963; Forrester, 1968b). Levers L1 and L4 reinforce each other, as do L2 and L5, as well as L3 and L6.

There is more. That middle stock of good systems thinkers helps make sure that good systems modelling gets done and then creates another reinforcing loop because more good system thinking experience is created. We now have a system with at least four positive feedback loops. The over-arching logic to get it started says: shout about who and what are out there; communicate successes. This will help bring systems modelling deeper into the policy arena.

\section{Systems Modelling in the Anthropocene Era}

This paper argues that systems modelling can improve mental models and hence policy itself. Two caveats are worth making, however. First, we must acknowledge that systems scientists can have naïve mental models in exactly the same way as everyone else. So we could ourselves be accused of having conducted only a limited search, of coming to that conclusion too quickly, of falling victim for our own simplified mental model, or restricted worldview. Second, systems modelling is certainly not the only thing that might be useful - that is not the argument being made. But it has proved to be useful at times and there are reasons for thinking that it can contribute further. So we hold to the view - supported outside the field (Lezak \& Thibodeau, 2016) that system modelling has something unique to offer in the context of the policy interventions relating to the Anthropocene.

If there is a tool available that plausibly offers to help then it merits consideration. It is easy to feel that the systems we are in are just 'out there', influencing us. This is false. Whether we think in terms of Habermas' Lifeworld and System, Bourdieu's Habitus and Field, or some other integrative sociological theories, human agency and social structure are intertwined (Layder, 1994; Ritzer, 1996). That perspective helps us understand that influence runs two ways (Fig. 7). Social structures give rise to patterns of conduct which enable and constrain. These are internalised by us and so our mental models are indeed shaped by social structures. However, those mental models motivate our social actions, actions which, in turn, can influence social structures. Systems modelling can play in a role in understanding such processes (Lane, 2001; Lane \& Husemann, 2002). 


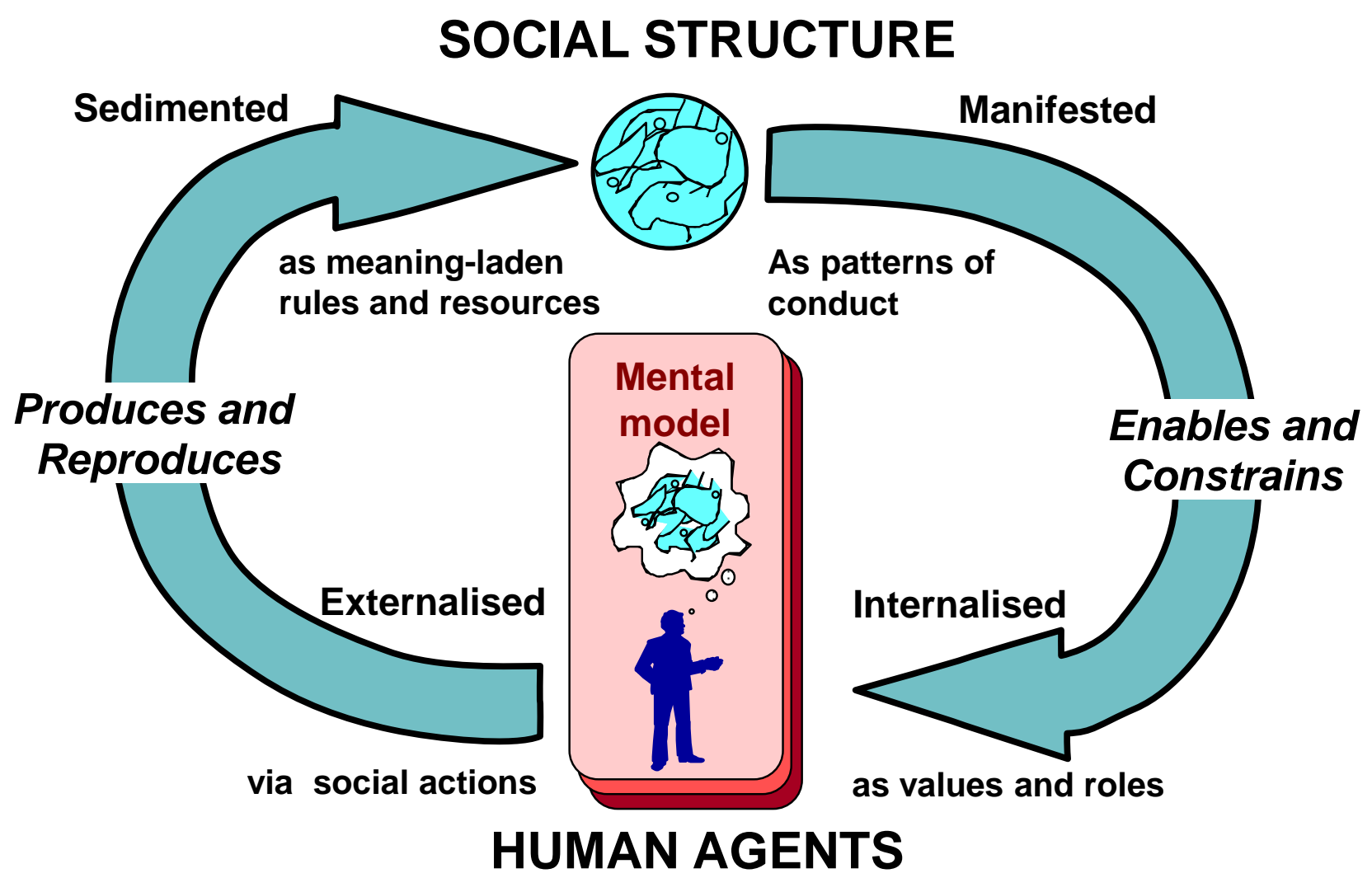

Figure 7: One representation of the interplay between the actions of human agents and the social structures within which they act. From Lane \& Husemann (2002).

The influence that humans have on the world has become increasingly apparent in recent decades and is what led to the idea of the 'Anthropocene Era' (Crutzen \& Stoermer, 2000; Crutzen, 2002). The term is not unproblematic. For example, its precise definition and timing are still debated (Kolbert, 2011). Malm \& Hornborg (2014) see the idea as over-reliant on natural scientific approaches, too commodious in attributing responsibility to a whole species and analytically deficient with respect to cultural and power effects. On that last concern, Klein (2016) observes:

"These ways of explaining our current circumstances have a very specific, if unspoken meaning: that humans are a single type, that human nature can be essentialised to the traits that created this crisis. In this way, the systems that certain humans created, and other humans powerfully resisted, are completely let off the hook. Capitalism, colonialism, patriarchy - those sorts of system." (Klein, 2016, p. 12) 
Nevertheless, the Anthropocene idea attempts to communicate the integrative nature of the relationship between human behaviour and the eco-system. ${ }^{4}$ In so doing, it points to a significant attribute of our times:

"The currently unfolding discourse on the Anthropocene represents a convergence of Earth System natural science and post-Cartesian social science ... Both fields suggest that the Enlightenment distinction between Nature and Society is obsolete. Now that humanity is recognised as a geological force, the story goes, we must reconceptualise not only the relations between natural and social sciences but also history, modernity and the very idea of the human." (Malm \& Hornborg, 2014, p. 62)

Systems do shape us and we shape systems. That insight, central to integrative sociological theories, takes on a new relevance in the Anthropocene Era. An early version of that relevance is expressed by David Attenborough at the end of his account of the evolution of life on earth (Attenborough, 1979). Having spent the whole final chapter on one species, Homo sapiens, he observes:-

"This may have given the impression that somehow man is the ultimate triumph of evolution, that all these millions of years of development have had no purpose other than to put him on earth. There is no scientific evidence whatsoever to support such a view ...

But although denying that we have a special position in the natural world might seem becomingly modest in the eye of eternity, it might also be used as an excuse for evading our responsibilities. The fact is that no species has ever had such wholesale control over everything on earth, living or dead, as we have now. That lays upon us, whether we like it or not, an awesome responsibility. In our hands lies not only our own future, but that of all other living creatures with whom we share the earth." (p. 308)

In the Anthropocene Era, we have shaped the eco-system and now that eco-system is shaping us. Yet, confronted by Morton's 'hyperobjects' and Jameson's incomprehensibility, we need not be supine. We have the opportunity and the tools to try to shape all of our social systems. At a global level Forrester said this in 1971 and called on policy makers to use systems modelling to address the issues that his work brought to light (Forrester, 1971). It is with that in mind that we offer a positive response to the question in this paper's title. Consider again the three cases described in this paper. An understanding of the possibility of unintended consequences and feedback is useful if a policy is to succeed: systems modelling can help in creating that understanding. An understanding of stock accumulation and of non-linearity has a role to play if effective fishery management policy and many other policies of the Anthropocene Era are to be formulated: systems

${ }^{4}$ In August 2016 a significant step in the institutional acceptance of the term was taken (Carrington, 2016). The 'Working Group on the Anthropocene' - an official expert group of the Sub-commission on Quaternary Stratigraphy, a constituent body of the International Commission on Stratigraphy which itself is part of the International Union of Geological Sciences - voted in favour of its adoption as an official term. This recommendation was presented at the meeting of the International Geological Congress in Cape Town, South Africa on 29th August. The proposed start date for the epoch is 1950, based primarily on the presence of radioactive elements released by nuclear weapons testing but also relating to soot emissions from power stations, the accretion of bones from domesticated chickens and the spread of plastic-based pollutants (see also Waters, et al., 2016). Work will continue to identify the most appropriate geological signals. 
modelling can help in creating that type of understanding. An understanding of different worldviews and different ways of making sense of human behaviour is surely useful in finding effective interventions: systems modelling can help in creating these. Across the approaches showcased in this paper and the others that make of System Science, systems modelling has the potential to contribute significantly to policy making; indeed, this has long been the aspiration, whether the issue is local or global. ${ }^{5}$ In the Anthropocene Era there is a need and an opportunity to use systems modelling to try to improve our mental models, to emulate Dickens' protagonist, Stephen Blackpool, who pondered his world;

"till the muddle in my mind have cleared awa".

\section{ACKNOWLEDGEMENTS}

Grateful thanks are given to the following.

Ray Ison: for inviting DCL to attend the meeting 'Governing the Anthropocene: Cyber-systemic Possibilities' at Herrenhausen Palace, Hannover, Federal Republic of Germany, $30^{\text {th }}-31^{\text {st }}$ July 2015. The Volkswagen Stiftung and WINS (Berlin Workshop in Institutional Analysis of Social-Economic Systems) at Humboldt-Universität zu Berlin who together funded DCL's attendance at the Hannover workshop. Sarah Cornell of the Stockholm Resilience Centre at Stockholm University: she used the James Rennell quotation at the Hannover meeting and graciously provided the original and its source. Jonathan Flowers: who provided the specifics (in large, friendly letters) of a reference. Two referees who provided helpful comment and correction on the originally submitted version.

\section{REFERENCES}

Adams D and Perkins G. 1985. The Hitch-Hiker's Guide to the Galaxy: The Original Radio Scripts. Pan Books: London. Adhikari S and Ivins ER. 2016. Climate-driven polar motion: 2003-2015. Science Advances 2: published online 08 Apr. Ashby WR. 1958. Requisite variety and its implications for the control of complex systems. Cybernetica 1: 83-99.

Attenborough D. 1979. Life On Earth: A natural history. Collins: London.

Axelrod R. 1976. Structure of Decision: The cognitive maps of political elites. Princeton University Press: Princeton.

Barber M. 2015. How To Run A Government (So that citizens benefit and taxpayers don't go crazy). Penguin: London.

Barnabè F. 2015. Managerial Myopia in Mismanaging Renewable Resources: The GONE FISHING Game. Simulation \& Gaming 46: 763-791.

Black L and Andersen DF. 2012. Using Visual Representations as Boundary Objects to Resolve Conflict in Collaborative Model-Building Approaches. Systems Research and Behavioral Science 29: p194-208.

Booth-Sweeney L and Sterman JD. 2000. Bathtub Dynamics: Initial results of a systems thinking inventory. System

${ }^{5}$ This can be seen in the case of System Dynamics (Forrester, 1961a), SSM (Checkland, 1981; Checkland \& Scholes, 1990), indeed, across the suite of approaches that make up Systems Science (Lane \& Jackson, 1995) and the careers of its leading exponents such as Churchman, Ackoff, Miser and Beer (respectively Mason, 2004; Kirby \& Rosenhead, 2005; Rothkopf, 2005; Rosenhead, 2006). 


\section{Dynamics Review 16: 249-286.}

Bradley S. 2015. The Railways: Nation, Network and People. Profile Books: London.

Bryant J. 1984. Modelling Alternative Realities in Conflict and Negotiation. Journal of the Operational Research Society 35: $985-993$.

Carrington D. 2016. The Anthropocene Epoch: Scientists declare dawn of human-influenced age. The Guardian newspaper, 29th August.

Carson R. 1962. Silent Spring. Houghton Mifflin: Boston.

Checkland PB. 1981. Systems Thinking, Systems Practice. Wiley: Chichester.

Checkland PB and Casar A. 1986. Vickers' concept of an appreciative system: a systemic account. Journal of Applied Systems Analysis 13: 3-16.

Checkland PB and Scholes J. 1990. Soft Systems Methodology in Action. Wiley: Chichester.

Conant RC and Ashby WR. 1970. Every Good Regulator Of A System Must Be A Model Of That System. International Journal of System Science 1: 89-97.

Crutzen PJ. 2002. Geology of mankind. Nature 415: 23.

Crutzen PJ and Stoermer EF. 2000. The "Anthropocene". The International Geosphere-Biosphere Programme (IGBP) Newsletter 41: 17-18.

de Steiguer JE. 1997. The Age of Environmentalism. McGraw-Hill: London.

Dörner D. 1990. The Logic of Failure. Philosophical Transactions of the Royal Society of London. Series B, Biological Sciences 327: 463-473.

Dörner D. 1996. The Logic of Failure: Recognising and avoiding error in complex situations (orig. Die Logik des Misslingens). Metropolitan Books: New York.

Doyle JK and Ford DN. 1998. Mental Models Concepts for System Dynamics Research. System Dynamics Review 14: 3-29.

Doyle JK and Ford DN. 2000. Mental Models Concepts Revisited: Some clarifications and a reply to Lane. System Dynamics Review 15: 411-415.

Fechner GT. 1860. Elemente der Psychophysik. Breitkopf \& Härtel: Leipzig.

Feduzi A and Runde J. 2014. Uncovering unknown unknowns: Towards a Baconian approach to management decisionmaking. Organizational Behavior and Human Decision Processes 124: 268-283.

Forrester JW. 1961a. Industrial Dynamics. MIT Press: Cambridge, MA.

Forrester JW. 1961b. Standard Symbols for Industrial Dynamics Flow Diagrams. MIT D-memo 41-1: 1-6.

Forrester JW. 1968a. Market growth as influenced by capital investment. Industrial Management Review (now the Sloan Management Review) 9: 83-105.

Forrester JW. 1968b. Principles of Systems. MIT Press: Cambridge, MA.

Forrester JW. 1970a. Counterintuitive behaviour of social systems. In Collected Papers of Jay W. Forrester (1975 collection) Wright-Allen Press: Cambridge, MA; pp. 211-244.

Forrester JW. 1970b. A World Dynamics Model: Introductory exercise. MIT D-memos 1348, 1353-5, 1357\&8 and 1360:

Forrester JW. 1971. World Dynamics. Wright-Allen Press: Cambridge, MA.

Franco LA and Hämäläinen RP (eds.). 2016. Behavioural Operational Research (Feature cluster in European Journal of Operational Research 249 3).

French S. 1988. Decision Theory. Ellis Horwood Limited: Chichester, UK.

Hammond JS, Keeney RL and Raiffa H. 1998. The Hidden Traps In Decision Making. Harvard Business Review 76: 47-58.

Hardin G. 1968. The Tragedy of the Commons. Science 162: 1243-1248.

Hoffman A and Jennings PD. 2012. The social and psychological foundations of climate change. Solutions 4: 58-65. 
Howard RA. 1966. Decision Analysis: Applied decision theory. In Proceedings of the fourth International Conference on Operational Methods eds. DB Herty and J Melese, Wiley-Interscience: New York; pp. 55-71.

Jackson MC. 2003. Systems Thinking: Creative holism for managers. Wiley: Chichester.

Jackson MC. 2009. Fifty Years of Systems Thinking for Management. Journal of the Operational Research Society 60: s24s32.

Jameson F. 1990. Cognitive Mapping. In Marxism and the Interpretation of Culture eds. C Nelson and L Grossberg, University of Illinois Press: Urbana and Chicago; pp. 347-360.

Keys P. 1988. A methodology for methodology choice. Systems Research 5: 65-76.

Kim H, MacDonald RH and Andersen DF. 2013. Simulation and Managerial Decision Making: A double-loop learning framework. Public Administration Review 73: 291-300.

King A and Crewe I. 2014. The Blunders Of Our Governments (revised and updated paperpack ed.). Oneworld: London.

Kirby M and Rosenhead JV. 2005. IFORS' Operational Research Hall of Fame: Russell L. Ackoff. International Transactions in Operational Research 12: 129-135.

Klein JH. 2000. Telling Stories: A metagame description of a conflict. Omega 28: 1-15.

Klein N. 2016. Let Them Drown: The violence of othering in a warming world (The Edward W. Said Lecture 2016). London Review of Books 38: 11-14.

Kolbert E. 2011. Enter The Anthropocene Age of Man. National Geographic 219: 60-61,64-65,69-73,75-77,79,81,83,85.

Kovbach LD. 1960. Life Can Be So Nonlinear. American Scientist 48: 218-225.

Kremkow J, Jin J, Komban SJ, Wang Y, Lashgari R, Li X, Jansen M, Zaidi Q and Alonso J-M. 2014. Neuronal nonlinearity explains greater visual spatial resolution for darks than lights. Proceedings of the National Academy of Sciences 111: 3170-3175.

Kunc M, Malpass J and White L (eds.). 2016. Behavioral Operational Research: Theory, Methodology and Practice. Palgrave Macmillan UK: London.

Kunzig R. 2009. The Big Idea: Climate Control (The Carbon Bathtub). National Geographic 2009: 26-29.

Lane DC. 1997. From Discussion to Dialogue: A Case Study Using an Interactive System Dynamics Modelling Approach. Journal of Decision Systems 6: 251-281.

Lane DC. 2001. Rerum cognoscere causas: Part II - Opportunities generated by the agency/structure debate and suggestions for clarifying the social theoretic position of system dynamics. System Dynamics Review 17: $293-309$.

Lane DC and Jackson MC. 1995. Only Connect! An annotated bibliography reflecting the breadth and diversity of systems thinking. Systems Research (now Systems Research and Behavioral Science) 12: 217-228.

Lane DC and Husemann E. 2002. Steering Away From Scylla, Falling Into Charybdis: The importance of recognising, simulating and challenging reinforcing loops in social systems. In Entscheiden in komplexen Systemen ed. PM Milling, Duncker \& Humblot: Berlin; pp. 27-68.

Lane DC and Husemann E. 2008. Steering without Circe: Attending to reinforcing loops in social systems (2007 Jay Wright Forrester Award address). System Dynamics Review 24: 37-61.

Lane DC, Munro E and Husemann E. 2016a. Blending systems thinking approaches for organisational analysis: reviewing child protection in England. European Journal of Operational Research 251: 613-623.

Lane DC, Munro E and Husemann E. 2016b. The Child Protection Jigsaw. Impact Spring: 42-45.

Layder D. 1994. Understanding Social Theory. Sage: London.

Lenton TM, Held H, Kriegler E, Hall JW, Lucht W, Rahmstorf S and Schellnhuber HJ. 2008. Tipping elements in the Earth's climate system. Proceedings of the National Academy of Science 105: 1786-1793.

Lewandowsky S, Gignac G and Oberauer K. 2013. The Role of Conspiracist Ideation and Worldviews in Predicting Rejection of Science. PLOS ONE 8: e75637.

Lezak SB and Thibodeau PH. 2016. Systems thinking and environmental concern. Journal of Environmental Psychology 
46: 143-153.

Linstone H. 1984. Multiple Perspectives for Decision Making: Bridging the gap between analysis and action. North Holland: New York.

MacKenzie D. 2012. Doomsday Book. New Scientist 2846: 38-41.

Malm A and Hornborg A. 2014. The geology of mankind? A critique of the Anthropocene narrative. The Anthropocene Review 1: 62-69.

Mansell J, Ota R, Erasmus R and Marks K. 2011. Reframing child protection: A response to a constant crisis of confidence in child protection. Children and Youth Services Review 33: 2076-2086.

Maruyma M. 1963. The Second Cybernetics: Deviation-amplifying mutual causal processes. American Scientist 51: 164179.

Mason RO. 2004. IFORS' Operational Research Hall of Fame: C. West Churchman. International Transactions in Operational Research 11: 585-588.

Meadows D, Fiddaman T and Shannon D. 1989. Fish Banks Ltd: A microcomputer-assisted group simulation that teaches principles for sustainable management of renewable resources. Monograph from Laboratory for Interactive Learning: University of New Hampshire, Durham, NH, USA.

Meadows DH. 2008. Thinking in Systems: A primer. Earthscan: London.

Meadows DH, Meadows DL, Randers J and Behrens WW. 1972. The Limits to Growth: A report for the Club of Rome's project on the predicament of mankind. Earth Island: London.

Merton RK. 1936. The Unanticipated Consequences of Purposive Social Action. American Sociological Review 1: $894-904$.

Morton T. 2010. The Ecological Thought. Harvard Business School Press: Boston, MA.

Moxnes E. 1998. Not Only The Tragedy Of The Commons: Misperceptions Of Bioeconomics. Management Science 44 1234-1248.

Moxnes E. 2000. Not Only The Tragedy Of The Commons: Misperceptions of feedback and policies for sustainable development (2000 Jay Wright Forrester Award address). System Dynamics Review 16: 325-348.

Murray JD. 1989. Mathematical Biology. Springer-Verlag: Berlin.

Nissen HJ, Damerow P and Englund RK. 1993. Archaic Bookkeeping: Writing and Techniques of Economic Administration in the Ancient Near East (P. Larsen Trans.). University of Chicago Press: Chicago and London.

Nutt P. 2002. Why Decisions Fail: Avoiding the blunders and traps that lead to debacles. Berret-Koehler: San Fransisco.

Pfeffer J. 1998. Six Dangerous Myths About Pay. Harvard Business Review 76: 109-119.

Pfeffer J. 2007. What Were They Thinking? Unconventional wisdom about management. HBS: Boston, MA.

Plous S. 1993. The Psychology of Judgement and Decision Making. McGraw-Hill: London.

Prebble L. 2012. The Effect. Bloomsbury: London.

Rennell J. 1832. An Investigation of the currents of the Atlantic Ocean, and of those which prevail between the Indian Ocean and the Atlantic. J. G and F. Rivington: London.

Ritzer G. 1996. Sociological Theory (4th ed.). McGraw-Hill: London.

Rockström J, Steffen W, Noone K, Persson Å, Chapin III FS, Lambin E, Lenton TM, Scheffer M, Folke C, Schellnhuber HJ, Nykvist B, Wit CAd, Hughes T, van der Leeuw S, Rodhe H, Sörlin S, Snyder PK, Costanza R, Svedin U, Falkenmark M, Karlberg L, Corell RW, Fabry VJ, Hansen J, Walker B, Liverman D, Richardson K, Crutzen P and Foley J. 2009. Planetary Boundaries: Exploring the Safe Operating Space for Humanity. Ecology and Society 14: 32. [online].

Rome A. 2015. The launch of Spaceship Earth (five prescient classics that first made sustainability a public issue in the 1960s and 1970s). Nature 527: 443-445.

Rosenhead J. 1992. Into the Swamp: The Analysis of Social Issues. The Journal of the Operational Research Society 43: 293-305.

Rosenhead JV. 2006. IFORS' Operational Research Hall of Fame: Stafford Beer. International Transactions in Operational 
Research 13: 577-581.

Rothkopf MH. 2005. IFORS' Operational Research Hall of Fame: Hugh Jordan Miser. International Transactions in Operational Research 12: 259-262.

Sims D. 2005. You Bastard: A Narrative Exploration of the Experience of Indignation within Organizations. Organization Studies 26: 625-1640.

Smyth DS and Checkland PB. 1976. Using a systems approach: the structure of root definitions. Journal of Applied Systems Analysis 5: 75-83.

Sterman JD and Booth Sweeney L. 2007. Understanding Public Complacency About climate Change: adults' mental models of climate change violate conservation of matter. Climatic Change 80: 213-238.

Sun JZ, Wang GI, Goyal VK and Varshney LR. 2012. A framework for Bayesian optimality of psychophysical laws. Journal of Mathematical Psychology 56: 495-501.

Tollefson J. 2009. Copenhagen: the scientists' view. Nature 462: 714-715.

Tversky A and Kahneman D. 1974. Judgment under uncertainty: heuristics and bias. Science 185: 1124-1131.

Tversky A and Kahneman D. 1981. The Framing of Decisions and the Psychology of Choice. Science 211: 453-458.

Vallery-Radot R. 1911. Chapitre IV (concerning Address given on the Inauguration of the Faculty of Science, University of Lille, 7th December 1854). In La vie de Pasteur (3rd ed.) Hachette: Paris; pp. 86-101.

Vennix JAM. 1996. Group Model-building: Facilitating team learning using system dynamics. Wiley: Chichester.

Vincent JL and Skowronski JM (eds.). 1981. Renewable Resource Management. Lecture Notes in Biomathematics 40. Springer: Heidelberg.

von Weizsaecker EU, Lovins AB and Lovins LH. 1995. Factor Vier: Doppelter Wohlstand - halbierter Naturverbrauch; Der neue Bericht an den Club of Rome. Droemer Knaur: Muenchen.

Wackernagel M, Schulz NB, Deumling D, Linares AC, Jenkins M, Kapos V, Monfreda C, Loh J, Myers N, Norgaard R and Randers J. 2002. Tracking the ecological overshoot of the human economy. Proceedings of the National Academy of Science 99: 9266-9271.

Wagenaar WA and Sagario SD. 1975. Misperception of Exponential Growth. Perception \& Psychophysics 18: 416-422.

Wagenaar WA and Timmers H. 1979. The Pond-and-duckweed Problem: Three experiments on the misperception of exponential growth. Acta Psychologica 43: 239-251.

Waters CN, Zalasiewicz J, Summerhayes C, Barnosky AD, Poirier C, Cearreta A, Edgeworth M, Ellis EC, Ellis M, Jeandel C, Leinfelder R, McNeill JR, Richter Dd, Steffen W, Syvitski J, Vidas D, Wagreich M, Williams M, Zhisheng A, Grinevald J, Odada E, Oreskes N and Wolfe AP. 2016. The Anthropocene is functionally and stratigraphically distinct from the Holocene. Science 351: 137-149.

Weick KE. 1995. Sensemaking in Organizations. Sage: London. 